IGUSABDER, 10 (2020): 123-129

\title{
Metoklopramid Kullanımı Sonrası Gelişen Malign Nöroleptik Sendrom: Olgu Sunumu
}

\author{
Sevil ALKAN ÇEVIKERR ${ }^{*}$ Emel YILDIZ ${ }^{* *}$, Mustafa YILMAZ ${ }^{* * *}$
}

\begin{abstract}
$\ddot{O} \mathbf{z}$
Malign nöroleptik sendrom (MNS), antipsikotik ilaçların nadir görülen bir yan etkisidir. Sendrom, rijidite, titreme, taşikardi, ateş yüksekliği, bilinç değişikliği, otonomik disfonksiyon, yüksek serum kreatinin fosfokinaz (CPK) ve lökositoz ile karakterize olan bir tablodur. Antipsikotik ilaç kullanan hastalarda MNS insidansı \%o,02-3 arasında değişir. Etiyolojide antiemetiklerin kullanımı, elektrolit düzensizlikleri (özellikle hipopotasemi), organik beyin sendromu, malnütrisyon da rol oynayabilir. MNS, yaşamı tehdit eden bir durum olup, tanı ve tedavisinde zorluk olabilir. Bu olgu sunumunda, bilinen kronik hastalı̆g gelişen tedavisi ve tanısında oldukça zorlandığımız bir malign nöroleptik sendrom olgusunun sunulması amaçlanmıştır.
\end{abstract}

Anahtar Kelimeler: Malign nöroleptik sendrom, metoklorpromid, yoğun bakım.

Malignant Neuroleptic Syndrome After Metoclopramide Use: Case Report

\begin{abstract}
Malignant neuroleptic syndrome (MNS) is a rare side effect of antipsychotic drugs. The syndrome is characterized by rigidity, tremor, tachycardia, fever, altered consciousness, autonomic dysfunction, high serum creatinine phosphokinase (CPK) and leukocytosis. The incidence of MNS in patients whom use antipsychotic drugs varies between $0.02-3 \%$. In the

\section{Olgu Sunumu (Case Report)}

Geliş / Received: 11.07.2019 \& Kabul / Accepted: 22.11.2019

${ }^{*}$ Uzm. Dr., Kütahya Sağlık Bilimleri Üniversitesi, Evliya Çelebi Eğitim Araştırma Hastanesi, Enfeksiyon Hastalıkları ve Klinik Mikrobiyoloji, Kütahya, Türkiye, E-posta: s-ewil@hotmail.com, ORCID ID https://orcid.org/0000-0003-1944-2477

** Uzm. Dr., Kütahya Sağlık Bilimleri Üniversitesi, Evliya Çelebi Eğitim Araştırma Hastanesi, Anesteziyoloji ve Reanimasyon, Kütahya, Türkiye, E-posta: dremelyldz@gmail.com, ORCIID IID https://orcid.org/0000-0003-4493-2099

**** Uzm. Dr., Kütahya Sağlık Bilimleri Üniversitesi, Evliya Çelebi Eğitim Araştırma Hastanesi Enfeksiyon Hastalıkları ve Klinik Mikrobiyoloji, Kütahya, Türkiye, E-posta: drmustafayilmaz29@hotmail.com, ORCID ID https://orcid.org/oooo-0001-6874$\underline{0169}$
\end{abstract}


etiology of MNS, use of antiemetics, electrolyte disorders (especially hypopotasemia), organic brain syndrome and malnutrition, may also play a role. MNS is a life-threatening condition and may have difficulty in diagnosis and treatment. In this case report, we aimed to present a case of malignant neuroleptic syndrome which we had difficulty in the treatment and diagnosis of a patient without known any chronic disease.

Keywords: Malignant neuroleptic syndrome, metoclopramide, intensive care.

\section{Giriş}

Malign nöroleptik sendrom (MNS), antipsikotik ilaçların nadir görülen bir yan etkisidir. Tipik ve atipik/antipsikotik ilaçlara ve tetrabenazin, lityum ve metoklopramid gibi antiemetikler gibi diğer dopamin reseptör bloke edici ilaçlara karşı potansiyel olarak yaşamı tehdit edici bir reaksiyondur ${ }^{1,2}$. Tanısında Delphi Konsessus tanı kriterlerinden yararlanılır. Bu kriterler;

1-Son 72 saat içinde dopamin antagonisti veya dopamin agonist çekilmesine maruz kalma,

2-Hipertermi $\left(38^{\circ} \mathrm{C}\right.$ üzerinde ateş),

3-Rijidite,

4-Bilinç bozukluğu,

5-Yükselmiş kreatinin fosfokinaz (CPK),

6-Otonomik instabilitedir (taşikardi, hipermetabolizma ve taşipne) ${ }^{1-4}$.

Sendrom, rijidite, titreme, taşikardi, ateş yüksekliği, bilinç değişikliği, otonomik disfonksiyon, yüksek serum CPK ve lökositoz ile karakterize olan bir tablodur. Antipsikotik ilaç kullanan hastalarda MNS insidansı \%o,02-3 arasında değişir. Etiyolojide antiemetiklerin kullanımı, elektrolit düzensizlikleri (özellikle hipopotasemi), organik beyin sendromu, malnütrisyon rol oynayabilir. MNS, yaşamı tehdit eden bir durum olup, tanı ve tedavisinde zorluk olabilir ${ }^{1-5}$. Bu olgu sunumunda bilinen kronik hastalığı olmayan hastada gelişen tedavisi ve tanısında oldukça zorlanılan bir malign nöroleptik sendrom olgusunun sunulması amaçlanmıştır. 


\section{OLGU}

Otuz sekiz yaşında erkek hasta acil servise yakınları tarafından ateş yüksekliği, bilinç değişikliği ile getirilmiştir. Öncesinde ilaç kullanımı olmayan hastaya 2 gün önce ishal, ateş ve kusma şikâyetleriyle gittiği bir acil polikliniğinde intravenöz (IV) yoldan metoklopramid yapıldığı ve metoklopramid tablet reçete edildiği öğrenilmiştir. Hastanın ilaca başladıktan sonra bilinç değişikliği gelişmesi üzerine acil servise getirildiği öğrenilmiştir. Fizik muayenesinde (FM); genel durumu orta, bilinci konfü, ajite, Glaskow Koma Skoru:9, ateş 39, $1^{\circ} \mathrm{C}$, kan basıncı 140/80 mmHg, kalp atım hızı 96 atım/dk, dakika solunum sayısı 18 idi. Her iki pupil çapı izokorik, ışık refleksi (+/+), ense sertliği şüpheli pozitif ve motor muayenede lateralizasyon bulgusu yoktu. Beyin tomografisinde herhangi bir patolojiye rastlanmamıştır. Hastadan istenen nöroloji konsültasyonu sonucunda kranial manyetik rezonans (MR) görüntülemesi istenmiştir. Patoloji saptanmamıştır. Laboratuvar tetkiklerinde lökosit 16,400/mm³, AST: 45 U/L, ALT: $192 \mathrm{U} / \mathrm{L}$, üre: $16 \mathrm{mg} / \mathrm{dL}$, kreatin: o,6 mg/dL, C Reaktif protein (CRP) $108 \mathrm{mg} / \mathrm{L}$, kreatin kinaz (CK): 1689 U/L olarak tespit edilmiştir. Elektrolit değerleri normaldi. Akciğer radyografisinde infiltratif görünüm yoktu. Fizik muayenede (FM) şüpheli ense sertliği dışında patolojik bulgusu yoktu. Hastaya bunun üzerine merkezi sinir sistemi enfeksiyonu ön tanısıyla lomber ponksiyon yapılmıştır. Beyin omurilik sıvısı (BOS) incelemesinde; BOS hücre sayımında hücreye rastlanmadı, BOS glikoz ve protein değerleri normaldi. Hasta yakın takip amaçlı yoğun bakım ünitesine alınmıştır. Hastaya ampirik olarak kan, idrar, BOS kültürleri ve ayrıca herpes ensefaliti ön tanısıyla BOS'tan Herpes PCR (polimeraz zincir reaksiyonu) tetkiki gönderildikten sonra seftriakson 2x2 gr IV+asiklovir 3x750 mg IV tedavileri başlandı. Hasta monitorize edilerek hidrasyon başlanmıştır. Ajitasyonları olan hastaya gerektiğinde 1-2 mg midazolam IV tedavisi verilmiştir. Yatışının 1. gününde arteriyel kan gaz analizi sonucu pH:7.21, pO2:51.2 mmHg, pCO2:46 mmHg olan ve solunum sikıntısı artan hasta entübe edilmiştir. Hastanın kültürlerinde üreme olmamıştır ve Herpes PCR negatif olarak saptanmıştır. FM bulguları ve öyküsü ile hastanın MNS olabileceği düşünülerek hastaya nazogastrik kateterden $3 \times 2,5 \mathrm{mg}$ bromokriptin tedavisi ve 1 gün sonra dantrolen $1 \mathrm{mg} / \mathrm{kg} / 6$ saatte bir başlanmıştır ve bromokriptin kesilmiştir. Tedavi ile ateş ve CPK değerleri düşmüştür. Takibinin 7. gününde arteriyel kan gaz patolojileri düzelmiş, sedasyon kesilmiş ve mekanik ventilasyondan ayrılmıştır. Klinik ve 
laboratuvar bulguları tamamen düzelen hasta şifa ile taburcu edilmiştir.

\section{TARTIŞMA}

Malign nöroleptik sendrom, santral nörotransmitterlerin oranındaki dengesizlik sonucu ortaya çıkan ve genellikle genç erişkinlerde görülen bir sendromdur ${ }^{1}$. Dört ana semptomla karakterize nadir görülen ancak potansiyel olarak ölümcül bir hastalıktır. Sunulan MNS mortalite oranı \% 5,6'dır². Başlıca komplikasyonlar rabdomiyoliz, akut böbrek hasarı, sistemik enfeksiyonlar ve venöz tromboembolizmdir3. Bunlar bilinç değişiklikleri, kas sertliği, hipertermi ve otonomik disfonksiyondur. Patofizyolojisinde dopamin reseptör antagonizması olduğu düşünülmektedir. Antipsikotiklerin kullanımına bağlı olarak görülebileceği gibi, Parkinson tedavisinde kullanılan dopamin agonistleri ve metoklopramid, proklorperazin ve prometazin gibi dopamin agonistleri kullanımına bağlı da görülebilir². Bu olguda metoklopramid kullanım öyküsü vardı. Diğer bir görüşe göre santral düzensiz sempato-adrenal hiperaktivite de MNS etiyolojisinde olası bir açıklama olarak öne sürülmüştür4. Her ne kadar bir dopamin antagonisti olan metoklopramidin ilk tercih edilecek ilaç olmasına, özellikle acil servislerde slk sık emezisin semptomatik tedavisinde kullanılmasına rağmen, metoklopramid ile tedavi, tardif diskinezi, distoni ve parkinsonizm gibi ciddi olumsuz

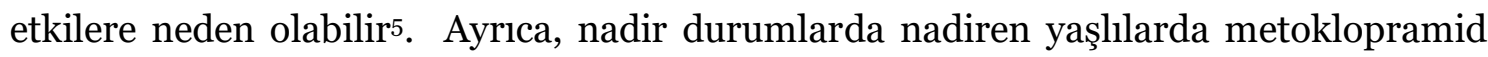
MNS'e neden olduğu birkaç olgu ile bildirilmiştir6 ${ }^{6}$. Tek metoklopramid dozu ile gelişebileceği gibi tekrarlayan dozlarla da gelişebilmektedir. Hastanın erken tanı ve tedaviden sonra herhangi bir komplikasyon olmadan tamamen düzeldiği gösterilmiştir. Her ne kadar metoklopramide bağlı MNS nadir görülürse de, bu ilacın klinik uygulamada yaygın olarak kullanıldığı ve MNS'a neden olmak için sadece tek bir dozun yeterli olabileceği akılda tutulmalıdır. $\mathrm{Bu}$ nedenle, metoklopramid ile tedaviye başlandıktan sonra açıklanamayan bilinç değişiklikleri, kas sertliği ve ateş yükselmesi durumunda MNS'dan şüphelenilmelidir.

Malign nöroleptik sendrom, genel olarak antipsikotik kullanımı sonrası rijidite ve hiperterminin yanı sıra, bol terleme, titreme, inkontinans, bilinç değişiklikleri, kalp atış hızı ve kan basıncındaki değişiklikleri içerir. Laboratuvar değerlerinde ise, lökositoz ve CPK yüksekliği ile karakterizedir5. Bu hastada da benzer semptomlar ve laboratuvar tetkik sonuçları vardı. 
Ayırıcı tanıda ensefalit, sıcak çarpması ve Serotonin Sendromu, malign hipertermi ve lityum intoksikasyonu gibi patolojiler dikkate alınmalıdır. MNS için risk faktörleri; polifarmasi, dehidratasyon, yetersiz beslenme, hızlı veya parenteral antipsikotik ilaç kullanılmasıdır. Serotonin sendromu akut başlangıçlıdır. MNS rijidite varken, serotonin sendromunda miyoklonus, klonuslu hiperrefleksi ve midriyazis görülür7 ${ }^{7}$ Etanol zehirlenmesi, özellikle yoksunluk, antikolinerjik ilaçların tamamlayıcı kullanımı ve lityum, organik beyin sendromu ve duygu durum bozukluğu gibi belirli koşullar, ajitasyon ve halsizlik gibi bazı durumların MNS'a neden olduğu bildirilmektedir ${ }^{8}$. Sunulan olgunun da ayırıcı tanı yapılması amaçlı lomber ponksiyon yapılmış, BOS inceleme bulguları ile merkezi sinir sistemi enfeksiyonu dışlanmıştır. Kullandığı ilaçların değerlendirilmesi sonucunda da diğer tanılar ekarte edilmiştir.

Yüksek CPK’n yanı sıra, laboratuvar bulguları olarak genellikle lökositoz, anormal elektrolitler, böbrek yetmezliği, anormal karaciğer fonksiyon testleri ve değişen koagülasyon test sonuçları saptanmaktadır`. Sunulan olguda da benzer tetkik sonuçları mevcuttu.

Spesifik tedavi daima ampiriktir, semptomların süresi ve ciddiyetine göredir. Tedaviye hidrasyon, elektrolit ve asit baz dengesizliğinin düzeltilmesi, aktif soğutma önlemleriyle vücut ısısının azaltılması ve kalp, solunum ve dolaşımın yakın izlenmesi ile başlanmalıdır. Benzodiyazepinler katatoni ve ekstrapiramidal semptomlar için kullanılabilir. Ağır vakalarda ve vücut 1 sısı $38.3^{\circ} \mathrm{C}$ ile $40.0^{\circ} \mathrm{C}$ arasında değişen hastalarda dopamin agonisti ile tedavi düşünülmelidir. Tedavide 8 saatte bir $2.5 \mathrm{mg}$ bromokriptin verilebilir. Vücut sıcaklı̆̆ $40^{\circ} \mathrm{C}^{\prime}$ den yüksekse, IV dantrolen 2mg-3 mg/kg dozda verilmelidir. Dantrolen, hidantoine türevi bir kas gevşetici olup, merkezi spesifik bloke ederek iskelet kaslarından kalsiyumu serbestleşmesini sağlar. Bu spastisiteyi azaltan kasları uyarma-kasılma mekanizmasını azaltır1o. MNS tedavisinde en etkin ilaç dantrolendir ve mortaliteyi önemli oranda azaltır11. Bromokriptin ve dantrolen, kalp ve solunum yetmezliği, miyoglobinürik böbrek yetmezliği, aritmiler, nöbet vb. gibi ciddi hipertermisi olan MNS hastalarında mortalite oranını önemli ölçüde azaltır. Hasta, klinik olarak ağır seyreden bir hastaydı. Bromokriptin ve dantrolen tedavisi verilmiştir. Mortaliteyi azaltabilmek için en doğru yaklaşım anormal otonomik disfonksiyonu, rijiditeye bağlı gelişen solunum sıkıntısı ve 
hemodinamikin stabilitenin yakın takip ve tedavisi için yoğun bakım tedavisinin etkin uygulanmasıdır ${ }^{12}$.

\section{Sonuç}

Sonuç olarak, nörologların, acil tıp hekimlerinin ve enfeksiyon hastalıkları uzmanlarının özellikle ateş ve bilinç bulanıklı̆̆ı tablosuyla gelen hastalarda MNS tanısını akılda tutmaları ve anamnezde nöroleptik ve antipsikotik ilaçlar ile nadir de olsa yaygın klinik uygulaması olan metoklopramid kullanımını ısrarla sorgulamaları hastalığın mortal gidişini önlemede çok önemlidir.

Hasta Onamı: Yazarlar "Bilgilendirilmiş Gönüllü Olur/Onam Formu"nun imzalatıldığını beyan etmişlerdir.

Çıkar Çatışması: Yazarlar çıkar çatışması bildirmemişlerdir.

Finansal Destek: Yazarlar bu çalışma için finansal destek almadıklarını beyan etmişlerdir.

\section{KAYNAKLAR}

1- Duma SR, Fung VS. Drug-induced movement disorders. Aust Prescr. 2019; 42(2):56-61. doi:10.18773/austprescr.2019.014.

2- Pileggi DJ, Cook AM. Neuroleptic malignant syndrome. Ann Pharmacother. 2016;50(11):973-981.

3- Isık AT, Soysal P. Neuroleptic malignant syndrome in an elderly patient with normal pressure hydrocephalus overlapping corticobasal degeneration. Am J Alzheimers Dis Other Demen. 2015;30(4):417-420. doi:10.1177/1533317514552668.

4- Gurrera RJ. Sympatho adrenal hyperactivity and the etiology of neuroleptic malignant syndrome. Am Psychiatry. 1999;156(2):169-180.

5- Oruch R, Pryme IF, Engelsen BA, Lund A. Neuroleptic malignant syndrome: an easily overlooked neurologic emergency. Neuropsychiatr Dis Treat. 2017;13:161175. doi: 10.2147/NDT.S118438. 
6- Kocyigit SE, Soysal P, Isık AT. Neuroleptic malignant syndrome associated with only one dose of metoclopramide in an older adult.Geriatr Gerontol Int. 2017;17(8):1232-1233. doi: 10.1111/ggi.13044.

7- Gurrera RJ, Mortillaro G, Velamoor V, Caroff SN. A validation study of the international consensus diagnostic criteria for neuroleptic malignant syndrome. $J$ Clin Psychopharmacol. 2017;37:67-71. doi: 10.1097/JCP.ooooooooooooo640.

8- Seitz DP, Gill SS. Neuroleptic malignant syndrome complicating antipsychotic treatment of delirium oragitation in medical and surgical patients: case reports and a review of the literature. Psychosomatics. 2009;50(1):8-15.

9- Gurrera RJ, Caroff SN, Cohen A, et al. An international consensus study of neuroleptic malignant syndrome diagnostic criteriausing the Delphi method. $J$ Psychiatr. 2011;72(9):1222-1228.

10- Krause T, Gerbershagen MU, Fiege M, Weisshorn R, Wappler F. Dantrolene-a review of its pharmacology, therapeutic use and new developments. Anaesthesia. 2004;59(4):364-373.

11- Guzé BH, Baxter LR. Current concepts. Neuroleptic malignant syndrome. N Engl J Med. 1985;313(3):163-166. doi:10.1056/NEJM198507183130306.

12- Adnet P, Lestavel P, Krivosic-Horber R. Neuroleptic malignant syndrome. $B r J$ Anaesth. 2000;85(1):129-135. doi:10.1093/bja/85.1.129. 